\title{
Pengaruh Pemberian Tepung Limbah Rumput Laut(Gracilaria sp.) dengan Aditif Multienzim dalam Pakan Terhadap Produksi Itik Tegal
}

\section{(The Impact of Giving Seaweed Waste Flour (Gracilaria sp) with Multienzyme Additive Toward The Production of Tegal Ducks)}

\author{
Manurung, J. P., Edjeng Suprijatna dan Vitus Dwi Y.B.I \\ Program Studi S-1 Peternakan Fakultas Peternakan dan Pertanian, \\ Universitas Diponegoro, Semarang \\ Email : jacomanoeroeng@gmail.com
}

Diterima : 18 Februari 2019

Disetujui : 20 Mei 2019

\begin{abstract}
ABSTRAK
Penelitian ini bertujuan untuk mengetahui pengaruh pemanfaatan limbah budidaya rumput laut dengan penambahan multienzim dalam pakan terhadap produktivitas itik tegal. Materi yang digunakan pada penelitian ini adalah 72 ekoritik tegal betina umur 22 minggu. Bahan pakan yang digunakan dalam penelitian terdiri dari jagung, bungkil kedelai, minyak, bekatul, tepung ikan, premix, methionine, lysine, limbah rumput laut Gracilaria sp. dan aditif multienzim allzyme SSF dari PT. Alltech dengan dosis $150 \mathrm{~g} /$ ton pakan. Penelitian dilakukan dengan Rancangan Acak Lengkap dengan 6 perlakuan dan 4 ulangan penelitian. Setiap unit percobaan terdiri dari 3 ekor itik. Pakan perlakuan yaitu : $T_{0}$ :pakan tanpa limbah rumput laut dan enzim ; $T_{1}$ : pakan tanpa limbah rumput laut + multienzim ; $T_{2}$ : pakan dengan limbah Gracilaria sp. 10\% + tanpa multienzim ; $T_{3}$ : pakan dengan limbah Gracilaria sp. 10\% + multienzim; $\mathrm{T}_{4}$ :pakan dengan limbah Gracilariasp. 12,5\% + multienzim; $\mathrm{T}_{5}$ :pakan dengan limbah Gracilaria sp. 15\% + multienzim. Hasil menunjukkan perlakuan tidak berpengaruh nyata $(P>0,05)$ terhadap produktifitas itik local. Kesimpulannya adalah penggunaan limbah rumput laut sampai taraf $15 \%$ dengan multienzim dalam pakan itik petelur tidak menurunkan produksi itik petelur.
\end{abstract}

Kata kunci: Itik tegal; limbah rumput laut; multienzim; produktivitas

\section{ABSTRACT}

This study aimed to determine the effect of utilization of seaweed waste with the addition of multienzyme towards tegal duck production. This study used 60 tegal ducks females aged 22 weeks. Feed ingredients used in the study consisted ofcorn, soybeanmeal, oil, rice bran, fish meal, premix, methionine, lysine, seaweed waste, gracilaria sp and multienzyme additives. This study was conducted with Complete Randomized Design with 6 treatments and 4 repeated researches. Each experimental unit consisted of 3 ducks. Ration treatments such as: $T 0$ : feed without seaweed waste and enzyme ; $T 1$ : feed without seaweed waste + multienzyme; T2 : feed with Gracilaria waste 10\% + with no multienzyme ; T3: feed with Gracilaria sp waste 10\% + multienzym ; T4 : feed with gracilaria waste 12,5\% + multienzyme; T5: feed with gracilaria sp waste 15\% + multienzyme. The result showed the treatment has no significant effect $(P<0,05)$ towards local ducks productivity. The 
conclusion is the use of seaweed waste until $15 \%$ with multienzyme in ducks didn't decrease the production of ducks.

Keywords: Tegal ducks, seaweed waste, multienzyme, productivity

\section{PENDAHULUAN}

Indonesia dikenal sebagai salah satu negara yang memiliki keanekaragaman hayati yang sangat kaya. Salah satu dari kekayaan itu adalah keanekaragaman hewan ternak, termasuk itik. Itik merupakan salah satu hewan unggas yang dapat dimanfaatkan daging dan telurnya untuk dikonsumsi manusia. Potensi ternak itik di Indonesia sangat besar terutama sebagi penghasil daging dan telur. Populasi itik di Indonesia sebagian besar dijumpai di pulau Jawa dan kepulauan Indonesiabagian Barat. Indonesia memiliki berbagai jenis itik lokal seperti itik Cirebon, itik Mojosari, itik Alabio, itik Tegal dan itik Magelang. Sebagian besar petenak itik sepanjang pantai utara jawa memilih itik tegal sebagai hewan ternak karena produksi itik tegal yang tinggi jika dibandingkan dengan komoditas itik lainnya.

Pakan merupakan biaya produksi tertinggi di dalam suatu usaha peternakan. Pemeliharaan itik secara intensif membutuhkan biaya yang tinggi dan sebagian besar dipengaruhi oleh biaya pakan (Purba dan Prasetyo 2014). Biaya pakan yang tinggi juga disebabkan karena penggunaan bahan pakan konvensionalyang bersaing dengan bahan pakan lainnya. Pakan konvensional yang semakin mahal mendorong untuk menemukan solusi untuk mencukupi kebutuhan yaitu dengan memanfaatkan bahan pakan local sebagai bahan pakan alternative. Salah satunya dengan memanfaatkan limbah rumput laut sebagai pakan ternak, akan tetapi pemanfaatan limbah rumput laut masih terbatas dikarenakan limbah rumput laut memiliki kandungan serat kasar berupa polisakarida yang sulit dicerna oleh enzim dalam saluran pencernaan (Suparmi dan Sahri2009).

Komposisi kimia rumput laut bervariasi sesuai dengan spesies dan kondisi lingkungan hidupnya. Komposisi kimia Gracilaria sp. secara spesifik mengandung kadar karbohidrat sebesar 42,59\%, kadar air sebesar $19,01 \%$, kadar abu sebesar $14,18 \%$, kadar serat kasar sebesar 10,51\%, kadar lemak sebesar $9,54 \%$,dan kadar protein sebesar 4,17\% (Soegiarto et al., 1978). Sebagian besarkomposisi kimia rumput laut tersusun atas karbohidrat yang dapat dicerna sebesar $53,10 \%$ dengan $10,51 \%$ berupa serat kasar. Berdasarkan hal tersebut maka diperlukan adanya suplementasi aditif enzim untuk membantu menurunkan kandungan serat kasar dan meningkatkan daya cernanya dalam saluran pencernaan ternak pada limbah rumput laut.

Menurut penelitin terdahulu teknologi pengolahan limbah rumput sebagai bahan pakan telah dilakukan. Menurut Padhi et al., (2003) melakukan percobaan pemberian rumput laut sebesar $0 \%, 25 \%, 5,0 \%$ dan $7.5 \%$, diperoleh hasil bahwa penambahan rumput laut sampai level $7,5 \%$ tidak mengganggu kinerja produksi telur, akan tetapi tidak 
berpengaruh nyata pada berat badan, konsumsi pakan dan produksi telur. Horhorrow et. al., (2009) menambahkan bahwa pengaruh pemanfaatan rumput laut dalam pakan dengan level 2,5-15\% terhadap kinerja ayam fase pullet menunjukkan tidak berpengaruh terhadap kandungan iodium. Situmorang et al., (2013) melaporkan bahwa perlakuan dengan penggunaan tepung rumput laut Gracilaria sp dengan level 2,5\%; $5 \%$ dan $7,5 \%$ secara nyata berpengaruh menurunkan konsumsi protein, namun tidak berpengaruh nyata terhadap pertambahan bobot badan, kecernaan protein kasar dan rasio efisiensi protein. Pemberian pakan yang mengandung limbah rumput laut terfermentasi telah diteliti pada itik lokal dan dapat dimanfaatkan hingga $15 \%$. Namun pada level yang lebih tinggi justru menurunkan kecernaannya dalam saluran pencernaan. Monica (2015) menyatakan bahwa penggunaan tepung limbah rumput laut fermentasi sampai level $15 \%$ menurunkan kecernaan protein, retensi nitrogen, dan pertambahan bobot badan, namun menghasilkan masa protein daging dan efisiensi protein yang sama. Sehingga dalam penelitian ini dilakukan suplementasi aditif enzim dalam upaya menghilangkan antinutrisi limbah rumput laut dan meningkatkan kecernaannya. Limbah rumput laut memiliki kandungan karaginan yang dominan bersifat mengikat air selain itu juga mengandung makromineral dan mikromineral yang esensial untuk tubuh. Itik mampu mencerna serat kasar lebih tinggi dibanding ayam.

Penelitian ini bertujuan untuk mengetahui pengaruh pemanfaatan limbah budidaya rumput laut dengan penambahan multienzim sebagai campuran pakan terhadap performans itik lokal yang meliputi konsumsi pakan, konversi pakan, dan hen day production (HDP) dan bobot telur.

\section{MATERI DAN METODE}

Materi yang digunakan pada penelitian ini adalah 72 ekor itik itik local betina umur 22 minggu. Kandang yang digunakan adalah20 petakkandang ukuran $60 \times 60 \times 100 \mathrm{~cm}$. Bahan pakan yang digunakan dalam penelitian meliputi jagung, bungkil kedelai, minyak, bekatul, tepung ikan, kapur, premix, methionine, lysine, limbah rumput laut Gracilaria sp. dan aditif multienzim. Pakan perlakuan yaitu: $\mathrm{T}_{0}$ : pakantanpa limbah rumput laut dan multi enzim ; $T_{1}$ : pakan tanpa limbah rumput laut + multienzim ; $T_{2}$ : pakan dengan limbah Gracilariasp. 10\% + tanpa multienzim; $\mathrm{T}_{3}$ : pakan dengan limbah Gracilaria sp. 10\%+ multienzim ; $\mathrm{T}_{4}$ : pakan dengan limbah Gracilariasp. 12,5\% + multienzim; $T_{5}$ :pakan dengan limbah Gracilaria sp. 15\% + multienzim. Komposisi dan kandungan bahan pakan dapat dilihat pada Table 1 dan Tabel 2.

Tahap persiapan teknis meliputi pembuatan tepung Gracilaria sp., Kegiatan yang dilaksanakan dalam tahap persiapan yaitu membuat tepung limbah rumput laut.Limbah rumput laut diperoleh dari daerah Brebes, Jawa Tengah.Tahap pertama yang dilakukan adalah menyortasi atau menyeleksi rumput laut daribendabenda asing seperti tali, lumut, kerang sumpil dan lain-lainnya. Pencucian 
dilakukan sebanyak 3 kali untuk hari. Menggiling rumput laut menggunakan menghilangkan pasir yang menempel pada mesin penggiling agar diperoleh bentuk limbah rumput laut. Menjemur rumput laut tepung.

hingga kadar air kurang lebih $14 \%$ selama 2

Tabel 1. Komposisi Pakan Perlakuan

\begin{tabular}{lcccc}
\hline Bahan pakan & T0 & T1 & T2 & T3 \\
\hline Jagung & 54,8 & 53,5 & 52,1 & 52,0 \\
Gracilaria sp. & 0 & 10,0 & 12,5 & 15,0 \\
Bungkil Kedelai & 17,2 & 17,5 & 17,5 & 17,6 \\
Minyak & 0,8 & 0,6 & 0,4 & 0,3 \\
Bekatul & 14,7 & 7,3 & 6,4 & 4,0 \\
Tepung Ikan & 7,0 & 7,0 & 7,0 & 7,0 \\
CaCO3 & 1,9 & 1,2 & 1,2 & 1 \\
Premix & 1,0 & 1,0 & 1,0 & 1,0 \\
Methionin & 0,4 & 0,4 & 0,4 & 0,4 \\
Lysin & 0,7 & 0,7 & 0,7 & 0,7 \\
Brotia costulla & 1,0 & 1,0 & 1,0 & 1,0 \\
\hline Total & $\mathbf{1 0 0}$ & $\mathbf{1 0 0}$ & $\mathbf{1 0 0}$ & $\mathbf{1 0 0}$ \\
\hline
\end{tabular}

Tabel 2. Kandungan Nutrisi Pakan Tiap Perlakuan

\begin{tabular}{lcccccc}
\hline \multirow{2}{*}{ Zat Nutrisi } & \multicolumn{6}{c}{ Perlakuan } \\
\cline { 2 - 7 } & T0 & T1 & T2 & T3 & T4 & T5 \\
\hline EM (kkal/kg)* & 2912,17 & 2912,17 & 2931,12 & 2931,12 & 2924,52 & 2901,24 \\
Protein kasar(\%)** & 18,19 & 18,19 & 18,04 & 18,04 & 18,00 & 18,02 \\
Lemak Kasar(\%)** $^{*} 8,10$ & 8,10 & 7,75 & 7,75 & 6,98 & 7,84 \\
Serat Kasar (\%)** & 6,77 & 6,77 & 5,98 & 5,98 & 6,14 & 6,42 \\
Methionin (\%) & 1,36 & 1,36 & 0,71 & 0,71 & 0,71 & 0,70 \\
Lysin (\%)* & 0,63 & 0,63 & 1,22 & 1,22 & 1,21 & 1,20 \\
Arginin (\%) & 1,24 & 1,24 & 1,15 & 1,15 & 1,15 & 1,12 \\
Ca (\%)** & 2,78 & 2,78 & 2,09 & 2,09 & 2,11 & 2,11 \\
P (\%)** & 0,73 & 0,73 & 0,66 & 0,66 & 1,55 & 0,67 \\
\hline
\end{tabular}

Keterangan: *) Sumber NRC (1994)

${ }^{* *}$ ) Dihitung berdasarkan Hasil Analisis Proksimat Fapet UGM

${ }^{* * *}$ ) Hasil Analisis Laboratorium IImu Nutrisi Pakan Fakultas Peternakan dan Pertanian Undip(2015)

Tahap perlakuan dilaksanakan selama 8 minggu pemeliharaan. Itik diberi pakan sesuai perlakuan. Itik diberi adaptasi kandang selama 2 minggu dan adaptasi pakan selam 4 hari secara bertahap yaitu $25 \%, 50 \%, 75 \%$ dan $100 \%$. Pakan diberi sebanyak $130 \mathrm{~g} /$ ekor/hari dan minum secara adlibitum.

Setiap hari dilakukan pengamatan selama penelitian yang meliputi menimbang sisa pakan untuk mengetahui jumlah konsumsi pakan, penimbangan 
bobot telur selama penelitian. Pengamatan produktifitas itik yang diukur adalah:

a. Konsumsi pakan adalah jumlah pakan yang dikonsumsi oleh ternak selama penelitian (8 minggu). Konsumsi pakan diperoleh dengan menimbang pakan yang diberikan dan mengurangi sisa pakan setiap hari, dinyatakan dalam satuan gram/ekor/hari.

b. Konversi pakan merupakan kemampuan itik mengkonversi pakan menjadi unit satuan telur yang dihitung setiap minggu selama penelitian (8 minggu).

Konversi pakan $=\frac{\text { Kg. Pakan }}{\text { Kg. Produksi telur }}$

c. Hen day Production (HDP) dihitung dari perbandingan jumlah telur (butir) yang dihasilkan dalam satu minggu dengan jumlah itik betina (ekor) yang ada dikalikan $100 \%$.

HDP $=\frac{\text { Produksi Telur Total/hari }}{\text { Total Populasi Kandang }} \times 100 \%$

d. Bobot Telur dihitung dengan menimbang tiap butir telur yang dihasilkan selam penelitan (g/butir).

\section{Rancangan Percobaan}

Rancangan yang digunakan dalam penelitian ini adalah Rancangan Acak Lengkap (RAL), dengan 6 perlakuan dan 4 ulangan dimana masing-masing perlakuan terdiri dari 3 ekor itik lokal.

Model Linear Rancangan Acak

Lengkap : $Y_{\mathrm{ij}}=\mu+\alpha \mathrm{I}+\varepsilon_{\mathrm{ij}}$

Keterangan :

$Y_{i j}=$ Hasil pengamatan pada perlakuan ke-

i, ulangan ke-j

i =Perlakuanke-i $(1,2,3,4,5)$

j = Ulangan ke-j dari 4 ulangan

$\mu=$ Nilai rata-rata umum dari seluruh perlakuan

$\mathrm{T}_{\mathrm{i}} \quad=$ Penambahan rumput laut dengan penambahan enzim ke -i

$\varepsilon_{\mathrm{ij}}=$ Galat perlakuan ke-i dan ulangan ke-j

\section{HASIL DANPEMBAHASAN}

Hasil penelitian penggunaan limbah rumput laut dengan aditif multienzim dalam pakan terhadap produktifitas itik petelur lokal disajikan pada Tabel 3.

Tabel 3. Rata-rata nilai konsumsi pakan, hen day production, konversi pakan dan bobot telur pada berbagai level limbah rumput laut dengan aditif multienzim.

\begin{tabular}{|c|c|c|c|c|c|c|}
\hline Parameter & T0 & $\mathrm{T} 1$ & T2 & T3 & T4 & T5 \\
\hline $\begin{array}{l}\text { Konsums } \\
\text { i Pakan }\end{array}$ & $122,74 \pm 1,26$ a & $\begin{array}{c}122,34 \pm 0, \\
74^{\mathrm{a}}\end{array}$ & $\begin{array}{c}122,26 \pm 0,92 \\
a\end{array}$ & $\begin{array}{c}122,28 \pm 1,95 \\
a\end{array}$ & $\begin{array}{c}122,06 \pm 1,04 \\
a\end{array}$ & $\begin{array}{c}122,91 \pm 0,52 \\
a\end{array}$ \\
\hline HDP & $\begin{array}{c}32,82 \pm 3,01 \\
b\end{array}$ & $33,67 \pm 5,39^{b}$ & $\begin{array}{c}38,27 \pm 6 \\
9^{a b}\end{array}$ & $\begin{array}{c}37,93 \pm 0,65 \\
\text { ab }\end{array}$ & $\begin{array}{c}44,05 \pm 3,06 \\
a\end{array}$ & $\begin{array}{c}40,82 \pm 1,75 \\
a\end{array}$ \\
\hline $\begin{array}{l}\text { Konversi } \\
\text { Pakan }\end{array}$ & $5,97 \pm 0,56^{a}$ & $5,92 \pm 1,12^{a}$ & $\begin{array}{c}5,23 \pm 1,0 \\
1^{\mathrm{ab}}\end{array}$ & $5,14 \pm 0,11^{\mathrm{ab}}$ & $4,44 \pm 0,28^{b}$ & $4,80 \pm 0,11^{b}$ \\
\hline Bobot & $63,00 \pm 0,32$ & $62,85 \pm 0,96^{a}$ & $62,75 \pm 0$ & $62,69 \pm 0,60$ & $62,60 \pm 0,37$ & $62,77 \pm 0,32$ \\
\hline Telur & a & & $42^{\mathrm{a}}$ & a & a & a \\
\hline
\end{tabular}

Keterangan : nilai rata-rata pada konsumsi pakandan bobot telur menunjukkan perbedaan tidak nyata $(P>0,05)$ sedangkan, Nilai Hen day production dankonversi pakan menunjukkan perbedaan nyata $(P<0,05)$ 


\section{Pengaruh Perlakuan terhadap Konsumsi Pakan}

Berdasarkan Tabel 4. data perlakuan menunjukkan bahwa konsumsi pakan pada masing-masing perlakuan T0, T1, T2, T3, T4 dan T5 secara berturut-turut adalah 122,74; 122,34; 122,26; 122,28; 122,06; 122,91; dengan rata-rata konsumsi pakan hasil penelitian sebesar 122,43gr. Ketaren dan Prasetyo (2002) melaporkan bahwa itik MA fase produksi pertama umur 20-43 minggu konsumsi pakan yaitu 154,56 g/ekor/hari, sedangkan Ketaren (2002) melaporkan bahwa total konsumsi pakan itik yaitu lebih dari $170 \mathrm{~g} / \mathrm{ekor} /$ hari.

Konsumsi pakan pada penelitian ini lebih rendah jika dibandingkan dengan konsumsi pakan hasil penelitian terdahulu. Pada penelitian ini konsumsi pakan pada TO dan T1 tidak berbeda walaupun dengan penambahan enzim, hal ini disebabkan oleh handungan nutrient tiap perlakuan hampir sama, seperti yang ditunjukkan pada Tabel 3. bahwa kandungan energi metabolis, protein dan serat kasar pada pakan untuk tiap perlakuan $\mathrm{T} 0, \mathrm{~T} 1, \mathrm{~T} 2, \mathrm{~T} 3, \mathrm{~T} 4, \mathrm{~T} 5$ sesuai dengan kebutuhan ternak. Hal ini sesuai dengan pendapat Tangendjaja et al. (1992) melaporkan bahwa ternak itik toleran terhadap pemakaian dedak dalam pakan sampai $60 \%$ dengan kandungan serat kasar $23 \%$, sehingga penggunaan enzim tidak mempengaruhi konsumsi pada tiap perlakuan. Hal ini sesuai dengan pendapat Lyons (1997) yang melaporkan bahwa penggunaan enzim antara lain mampu memaksimalkan penggunaan pakan yang bersifat konvensional, memaksimumkan penggunaan limbah dan bahan makanan yang bersifat non konvensional.

\section{Pengaruh Perlakuan terhadap Hen Day Production (HDP)}

produksi telur harian (HDP) pada masing-masing perlakuan $\mathrm{T} 0, \mathrm{~T} 1, \mathrm{~T} 2, \mathrm{~T} 3, \mathrm{~T} 4$, T5 secara berturut-turut adalah 32,82 ; 33,$67 ; 38,27 ; 37,93 ; 44,05 ; 40,82$ dengan rata-rata produksi telur selama penelitian adalah 37,93. Data yang hampir sama dilaporkan Hardjosworo (1989) bahwa 42,7\% itik Tegal kemampuanproduksi telurnya kurang dari $50 \%$.

Hasil penelitian ini menunjukkan bahwa penggunaan limbah rumput laut pada perlakuan T4 dan T5 produksi telur mengalami peningkatan jika dibandingkan perlakuan T0, T1, T2 dan T3 dikarenakan Asupan energi dan protein sangat berguna untuk memenuhi kebutuhan hidup pokok, aktivitas harian dan produksi telur seekor itik. Brand et al. (2003), menyatakan bahwa pembentukan telur dipengaruhi oleh besarnya konsumsi energi dan protein pakan. Secara teoritis peningkatan kandungan PK dalam pakan dan konsumsi PK dapat meningkatkan produksi telur (Wahyu, 2004).

Kandungan rumput laut pada taraf $15 \%$ pada pakan tidak berbeda terhadap konsumsi pakan tanpa rumput laut karena multi enzim yang terkandung dalam pakan memberi dampak peningkatan kecernaan terhadap pakan yang dikonsumsi ternak. Menurut Selle et al. (2003) yang menyatakan bahwa penambahan enzim kompleks (protease, sellulase, dan hemisellulase) dapat meningkatkan pertambahan bobot badan dan efisiensi penggunaan pakan dan mengoptimalkan pencernaan pakan sehingga kinerja ternak meningkat. hal serupa juga disebutkan 
Aderemi et al. (2006) yang menyampaikan bahwa, penggunaan enzim komersial yang mengandung multienzim mampu memperbaiki penampilan produksi telur dan efisiensi penggunaan pakan.

\section{Pengaruh Perlakuan terhadap Konversi Pakan}

Nilai konversi tiap pelakuan T0, T1, T2, T3, T4 dan T5 secara berturut-turut 5,97; 5,$92 ; 5,23 ; 5,14 ; 4,44 ; 4,80$ dengan rata-rata konversi pakan selama penelitian ini adalah 5,30 . Rata-rata konversi pakan pada penelitian ini lebih tinggi jika di bandingkan dengan nilai konversi pakan pada penelitian terdahulu. Data yang hampir sama juga disampaikan oleh Ketaren dan Prasetyo (2002) bahwa rataan konversi pakan itik Tegal betina selama 8 minggu sebesar 3,43 , sedangkan menurut hasil penelitian yang telah dilakukan oleh Arifah et al., (2013) melaporkan bahwa rata-rata konversi pakan itik tegal yaitu 4,48 .

Nilai konversi pakan pada ternak itik sangat berhubungan dengan kandungan serat dalam pakan. Limbah rumput laut Gracilaria sp. memiliki kandungan serat kasar berupa polisakarida yang sulit dicerna oleh enzim dalam saluran pencernaan. Sesuai dengan pendapat Aslan (1995) komponen yang terkandung dalam rumput laut diantaranya adalah algin, agar-agar dan karagenan yang digolongkan kedalam polisakarida mudah larut. Suprijatna et al., (2008) menyampaikan bahwa penambahan enzim selulase, protease, phytase, dan lipase dalam pakan unggas berfungsi memperbaiki efisiensi pakan, dapat mengoptimalkan proses pencernaan bahan pakan sehingga dapat meningkatkan pertambahan berat badan. Setiawan (2002) melaporkan bahwa penambahan $0,20 \%$ enzim kompleks pada pakan komersial dapat memperbaiki efisiensi penggunaan pakan pada ayam sebesar $12,20 \%$ lebih tinggi jika dibandingkan dengan tanpa penggunaan enzimkompleks.

\section{Pengaruh Perlakuan terhadap Bobot Telur}

Bobot telur pada masing-masing perlakuan T0, T1, T2, T3, T4 dan T5 secara berturut-turut adalah 63,$00 ; 62,85 ; 62,75$; 62,$69 ; 62,60 ; 62,77$. Dengan rata-rata berat telur selama penelitian $62,78 \mathrm{~g}$. Dengan rata-rata berat telur selama penelitian $62,30 \mathrm{~g}$. Hasil yang diperoleh selama penelitian ini masih dalam kisaran normal sesuai dengan pendapat Subiharta et al. (2001) berat telur itik Tegal hasil seleksi generasi pertama sekitar $48 \mathrm{~g} /$ butir dan generasi kedua $50 \mathrm{~g} /$ butir. Penambahan limbah rumput laut dan multi emzim sampai taraf $15 \%$ dalam pakan tidak mempengaruhi berat telur. Tidak berpengaruhnya penggunaan limbah rumput laut dalam pakan disebabkan karena bobot telur sangat dipengaruhi oleh protein yang dikonsumsi, karena protein digunakan untuk sintesis protein albumen dan kuning telur. Semakin banyak jumlah protein yang dikonsumsi, maka protein yang digunakan untuk sintesis protein albumen dan kuning telur juga meningkat.

Limbah rumput laut dan aditif multi enzim bukan merupakan sumberprotein pakan dan pada penelitian ini kandungan protein pada tiap perlakua baik T0 (pakan tanpa rumput laut dan tanpa multienzim) ataupun T5 (15\% rumput laut dengan multienzim) relatif sama sekitar $18 \%$, 
mengakibatkan bobot telur juga sama, maka bobot telur tidak berbeda nyata. Menurut Kompiang (2000) bahwa pemberian probiotik dalam pakan dan air minum juga berpengaruh tidak nyata terhadap rataan bobot telur. Hal serupa juga disebutkan oleh Mahdavi et. al., (2005) melaporkan bahwa suplementasi probiotik pada ayam petelur tidak meningkatkan bobot telur. Pasaribu et al. (2005) mengatakan bahwa, kandungan protein pada pakan akan mempengaruhi komposisi telur dan bobot teluryang dihasilkan. Argo et al,. (2013) menambahkan bahwa kandungan protein dan asam amino dalam pakan mempengaruhi pula terhadap berat telur.

\section{KESIMPULAN}

Kesimpulan penelitian ini yaitu penggunaan limbah rumput laut dengan aditif mulitienzim sampai pada taraf $15 \%$ tidak mempengaruhi konsumsi dan bobot telur tetapi meninggkatkan efisiensi penggunaan pakan dan produksi telur sehingga penggunaan limbah rumput laut dapat digunakan sampai taraf $15 \%$.

\section{SARAN}

Penggunaan limbah rumput laut dengan aditif multi enzim dalam ransum itik petelur sampai level $15 \%$ masih dapat digunakan sebagai bahan pakan alternative untuk meningkatkan produksi telur itik, Sehingga, perlu adanya penelitian lanjutan dengan menggunakan jenis enzim yang lain sehingga mampu meningkatkan kualitas limbahrumputlautsebagaibahan pakan.

\section{DAFTAR PUSTAKA}

Aderemi A, D.R. 2007. Sifat Fisik dan Fungsional Tepung Putih Telur Itik dengan Penambahan Taraf Asam Sitrat yang Berbeda. Skripsi. Program Studi Teknologi Hasil Ternak Fakultas Peternakan Institut Pertanian Bogor.

Arifah, N., Ismoyowati. Iriyanti. N. 2013. Tingkat Pertumbuhan Dan Konversi Pakan Pada Berbagai Itik Lokal Jantan (Anas Plathyrhinchos) Dan Itik Manila Jantan (Cairrina Moschata). Fakultas Peternakan UniversitasJenderal Soedirman. Purwokerto. Jurnal Ilmiah Peternakan 1(2):718-725.

Argo, L. B., Tristiarti dan I. M. Mangisah. 20013. Kualitas Fisik Telur Ayam Arab Petelur Fase I Dengan Berbagai Level Azolla Microphylla. Animal Agriculture Journal. 2 (1): 445-457.

Aslan, M. Laode, Budidaya Rumput Laut, PenerbitKanisius, 1995, 11-34.

Brand, Z., T. S. Brand and C. R.Brown. 2003. Tfe effect of dietery and protein levels on production in breeding female ostrich. British Poultry Science. 44 (4): 589-606.

Hardjosworo, P. 1989. Budidaya Itik Petelur. Fakultas Politeknik Pertanian IPB. Bogor.

Horhorow WM, Wihandoyo, Tri Yuwanta. 2009. Pengaruh Pemanfaatan Rumput Laut Gracilaria Edulis Dalam Pakan Terhadap Kinerja Ayam Fase Pullet. Buletin Peternakan Vol 33(1): 8-16 
Ketaren, P.P dan L.H. Prasetyo. 2002. Pengaruh Pemberian Pakan Terbatas Terhadap Penampilan Itik Silang Mojosari x Alabio (MA) umur 8 Minggu. Pros. Lokakarya Unggas Air. Pengembangan Agribisnis Unggas Air sebagai Peluang Usaha Baru. Ciawi, 5-6 Agustus 2001. Fakultas Peternakan IPB BogorBalai Penelitian Ternak, Bogor. HIm. 105-110

Ketaren, P.P. 2002. Kebutuhan Gizi Itik

Petelur Dan Itik Pedaging.

Wartazoa. 12(2):37-46

Kompiang, I.P. 2000. Pengaruh Suplementasi KulturBacillus Spp. Melalui Pakan Atau Air Minum Terhadap Kinerja Ayam Petelur. Jitv 5: 205-209

Lyons, T.P. 1997. A new era in animal production: the arrival of scientifically proven naturalalternatives. In 11th annual Asia Pacific Lecture Tour. 1-18.

Mahdavi, A.H;H.R.Rahmani dan Pourreza. 2005. Effect of Probiotic Supplements on Egg Quality and Laying Hen's Performance. International Journal of Poultry Science. Vol. 4 (7): 488-492

Monica, S. 2015. Kemampuan Deposisi Protein Tubuh pada Itik Pengging Jantan yang Diberi Tepung Limbah Rumput Laut (Gracilaria sp) Fermentasi. Skripsi. Fakultas Peternakan dan Pertanian. Undip.

Padhi, M K., Rai, R.B., Chandra, P., Senani, S., Saha, S.K., dan Ahlawat, S.P.S. 2003. Effect of feeding seaweeds on performance of Nicobari layer Animal Sciences. 73:8, 948•949.

Pasaribu, T. Sinurat, A. P., Purwadaria, T., Togatorop, M. H. 2005. Pemanfaatan bioaktif tanaman sebagai "feed additive" pada ternak unggas: Pengaruh pemberian gel lidah buaya atau ekstraknya dalam pakan terhadap penampilan ayam pedaging. JITV, 8(3), 139-145.

Purba M, Prasetyo LH. 2014. Respon pertumbuhan dan produksi karkas itik pedaging EPMp terhadap perbedaan kandungan serat kasar dan protein dalam pakan. JITV 19(3): 220-230.

Selle, P. H., K. H. Huang and W. I. Muir. 2003. Effect of Nutrient Specifications and Xylanase plus Phytase Supplementation of Wheta Bared Pakans on Growth Performance and Carcass Traits of Broiler Chicks. Asian-Aust. J. Anim. Sci. 16 (10) : 1501 - 1509 .

Setiawan, I. G. 2002. Pengaruh Penambahan Enzim Kompleks dalam Pakan Komersial terhadap Penampilan Ayam Pedaging. Skripsi, fakultas Peternakan, Universitas Udayana, Denpasar.

Situmorang N. A., L.D. Mahfudz, dan U. Atmomarsono. 2013. Pengaruh Pemberian Tepung Rumput Laut (Gracilaria Verrucosa) Dalam Pakan Terhadap Efisiensi Penggunaan Protein Ayam Broiler. Animal Agricultur al Journal. 2(2):49-56. 
Soegiarto, A. W, S. Atmaja, Sulistijo Dan H. Suprijatna, E. S. Kismiati dan N.R. Furi. 2008. Mubarak. 1987. Rumput Laut, Penampilan Produksi Dan Kualitas Manfaat, Potensi Dan Usaha Budidayanya. Lembaga Oseanologi Nasionl LIPI, Jakatra.

Subiharta, L. H. Prasetyo, S. Prawirodigdo, D. Pramono, Y. C. Raharjo, B. Budiharta dan Hartono. 2001. Seleksi Itik Tegal berdaya hasil tinggi. Laporan Penelitian kerjasama PemerintahKabupaten Brebes dengan BPTP Jawa Tengah.

Suparmi dan Achmad Sahri, 2009. Mengenal Potensi Rumput Laut: Kajian Pemanfaatan Sumber Daya Rumput Laut Dari Aspek Industri Dan Kesehatan. 44 (118): 95-116. Telur Pada Puyuh (Coturnix Coturnix Japonica) YangMemperoleh Pakan Protein Rendah Disuplementasi Enzim Komersial. J.Indon.Trop.Anim. Agric. 33 (1):66-71.

Tangendjaja, B., R. Matondang dan J.A. Diment. 1992. Perbandingan itik dan Ayam Petelur pada Penggunaan Dedak dalam Pakan dalam Fase Pertumbuhan. Majalah Ilmu dan Peternakan Vol. 2 (4): 137-139.

Wahju, J.2004. Ilmu Nutrisi Unggas. Cetakan ke-5. Gadja Mada University Press, Yogyakarta. 